\title{
LAS TEORÍAS FEMINISTAS DE LA TRADUCCIÓN A EXAMEN: DESTILACIONES PARA EL SIGLO XXI \\ Emilio Ortega Arjonilla \\ Universidad de Málaga
}

Las teorias feministas de la traducción a examen: destilaciones para el siglo XXI. Autora: Nuria Brufau Alvira.

Editorial: Editorial Comares, colección interlingua n ${ }^{\circ}$ 90, Granada, 2010.

Reseña: Emilio Ortega Arjonilla (Universidad de Málaga).

$\mathrm{N}^{\mathrm{o}}$ de páginas: 191.

Para comenzar con esta reseña de la obra de Nuria Brufau, titulada Las teorías feministas de la traducción a examen: destilaciones para el siglo XXI (publicada recientemente en la colección Interlingua de la Editorial Comares), debo apelar a la comprensión del lector de esta reseña. No soy un experto en Estudios de Género y Traducción, ni pretendo serlo. Si sigo, sin embargo, muy de cerca, la evolución que las reflexiones teóricas que en torno a la traducción y la Traductología se van produciendo, incluidas, lógicamente, las que se realizan desde presupuestos feministas o reivindicando un papel más visible y relevante (exento de prejuicios, si se prefiere) de la mujer, de lo femenino y de lo feminista en la construcción de teorías, enfoques y propuestas sobre la traducción.

Hecha la justificación inicial, no pedida, voy a basar mi reseña en dos afirmaciones y una convicción. Las afirmaciones, que suscribo plenamente, las tomo prestadas de José Santaemilia, el autor del prólogo (cf. p. XII, op. cit.). Son las siguientes:

La primera reza así: "con toda honestidad, creo que lo que menos necesita este libro es un prólogo, y sí una lectura atenta. Este libro - como la propia traducción feminista - no necesita ni prólogos, ni excusas, ni disculpas ni justificaciones (Barcardí \& Godayol 2008: 46)".

Y la segunda: "tenemos entre las manos un libro crítico, sincero, contagioso. Una historización detalladísima de los estudios feministas y de los estudios de traducción, que retrata con pasión el recorrido de las teorías feministas de la traducción desde sus inicios en Québec hasta su reciente, y entusiasta, recepción académica, con particular impulso en algunas universidades españolas". 
La convicción a la que aludía anteriormente se basa en el conocimiento previo de la autora. He seguido de cerca sus contribuciones, gracias a su participación en numerosos Congresos sobre traducción, en los que, en más de una ocasión, hemos compartido mesa y fructíferos debates. Me consta la minuciosidad con la que aborda los temas, y esta obra no es sino el colofón de una aventura académica llevada a cabo, con rigor y seriedad, bajo la sabia tutela de su directora, a la que dedica esta obra.

El resultado de la lectura atenta de la obra, como recomendaba en el prólogo José Santaemilia, no ha desmerecido el esfuerzo realizado. El objetivo, por tanto, de la presentación de la obra, en forma de reseña, no es otro que el de invitar a su lectura. Y aquí podría finalizar mi reseña. No obstante, en aras de una presentación más pormenorizada del contenido de esta obra, me haré eco de la estructura en la que se integra lo propuesto por Nuria Brufau en esta monografía y de algunas afirmaciones de la autora sobre los objetivos de la obra y sobre su propia percepción de la investigación llevada a cabo.

La obra aparece dividida en siete capítulos (o apartados), titulados como sigue:

Andamios

De la écriture féminine à la Woman Identified Translation

La Woman Identied Translation

La creación de un mito

A examen

La recepción académica de las teorías

Destilaciones

Le precede un prefacio de la autora, y un prólogo, firmado por José Santaemilia, y se cierra la obra con una extensa bibliografía sobre los temas objeto de estudio.

Hasta ahora he recurrido a voces externas para hablar de la obra de Nuria Brufau. Dejemos, ahora, que sea ella misma, la que nos exprese cuáles son sus intenciones. Y cito, de nuevo, la obra en cuestión (véase prefacio, p. XV): “de ahí que, inspirada en una concepción densa de revisión crítica, me proponga hurgar en las llamadas - y a menudo prejuzgadas -, cuasi onomatúrgicamente, teorías feministas de la traducción, escarbar en su historia, en su origen, en sus manifestaciones, en sus aplicaciones y en su recepción, con la intención no sólo de conocerlas mejor sino de ir (des)cubriendo y explicando sus fallas internas, así como aquellas en las que se ha incurrido respectivamente al importarlas sin traducirlas y al vilipendiarlas descontextualizándolas". 
No quiero interponer ningún velo o cortina de humo a la lectura directa de la autora. Su trabajo, exhaustivo y minucioso, valiente y crítico, acaba con una invitación a seguir con el "diálogo fructífero", con el contraste de pareceres, con la construcción de teorías que den cabida a los estudios de género, sin alardes pero también sin prejuicios.

Y termino esta reseña, ahora sí, recurriendo, de nuevo, a la autora. Quien mejor que ella para finalizar la presentación de su obra.

"Así las cosas, si las teorías quebequenses se toman como totales, algo que sus creadoras nunca pretendieron, entonces las críticas de Parker (1993), Arrojo (1994), von Flotow (1998a), Spivak (1992b, 1993) o Maier y Massardier-Kenney (1996), por referirme a las que la propia Martín Ruano menciona en su artículo, y porque son, en efecto, las más representativas, además de las de Moya (2005) o Vidal Claramonte (1999), son útiles a la hora de perfeccionar la búsqueda de un paradigma general en el que quepan todas las variaciones de sexualidad, clase y raza, que huya, por lo tanto, de bases dicotómicas y que pueda aplicarse como metodología al situarse ante cualquier traducción, un camino que responda a lo que Ortega Arjonilla llama el "vacío metodológico" del giro cultural, que, para este traductólogo, urge colmar si se quiere ser un referente futuro tanto para la práctica como para la teoría de la traducción (Ortega Arjonilla 2007: 82). Alambicados sus jugos, cabe extraer la esencia del feminismo traductor, la de la capacidad de traducción de participar legítimamente en un digno proyecto por la igualdad y que, actualizada, ofrezca una versión que entienda ese valor - este sí universal - en todas sus facetas. Adelante" (cf. p. 169, op. cit.). 